(c) The Author 2009. Published by Oxford University Press on behalf of the Society for the Study of French History. All rights reserved. For permissions, please e-mail: journals.permissions@oxfordjournals.org doi:10.1093/fh/crp005, available online at www.fh.oxfordjournals.org

\title{
PHILANTHROPIES CROISEES: A JOINT VENTURE IN PUBLIC HEALTH AT LYON (1917-1940)
}

\author{
PIERRE-YVES SAUNIER and LUDOVIC TOURNES*
}

\begin{abstract}
Since the end of the First World War the Rockefeller Foundation has spearheaded a large-scale programme in the field of education for the health professions (doctors and nurses). In several countries throughout the world, but with its efforts concentrated on Europe, it has financed schools, constructed information networks, granted research scholarships and awarded training bursaries. In so doing it has not, however, been in the business of propagating an irresistible 'American model', nor has it pursued a huge undertaking in disinterested aid. Through an attempt to contextualize these programmes, to bring to light the existence of common reference points, to retrace the work with local participants and to appraise cleavages within the philanthropic apparatus, this article proposes a fine-grained reading of the role of the Rockefeller Foundation at the Faculté de Médecine (Faculty of Medicine) and the Ecole d'Infirmières et d'assistantes sociales (Training School for Nurses and Social Workers) in Lyon between 1917- and 1940. It analyses these institutions in terms of the transactions, negotiations and appropriations that highlight their joint-venture character and it identifies their varied impact.
\end{abstract}

In Lyon the Ecole d'Infirmières and the Faculté de Médecine, situated respectively at 4 and 8 avenue Rockefeller, adjoin the Edouard Herriot Hospital and form part of a conglomeration of biomedical research laboratories recently named the 'Pôle Santé Rockefeller'. The presence of the American multimillionaire within the local place names originates in the investments which the Rockefeller Foundation, created in 1913, made in Lyon between 1922 and 1940. ${ }^{1}$ It financed the Ecole d'Infirmières to the tune of 50 per cent of the building costs $(\$ 160,000$ at current prices) and the Faculté to as much as 70 per cent $(\$ 800,000)$. This financial support took place within a general context of restructuring 'health

\footnotetext{
* Pierre-Yves Saunier is chargé de recherche at the Centre National de la Recherche Scientifique (research group 'Environnement Ville Société', Lyon, France). He may be contacted at pierre-yves. saunier@wanadoo.fr. Ludovic Tournès is maître de conférences at the University of Rouen. He may be contacted at ludovic.tournes@wanadoo.fr. The authors wish to thank the staff at the Rockefeller Archive Center and the Archives des Hospices Civils de Lyon and to acknowledge the help and hospitality of Madame Sallet, the former Directrice of the Ecole Rockefeller in Lyon.

${ }^{1}$ For an accessible general, but hardly impartial, view of the Foundation's history, written by one of its former presidents: R. B. Fosdick, The Story of the Rockefeller Foundation (New York, NY, 1952).
} 
practices' in France during the interwar period: a restructuring that affected the apparatus of public health, hospitals, the teaching of medicine and medical research, as well as national insurance. ${ }^{2}$ It was within this framework that a synergy developed between nursing education, medical education, hospital work and laboratory research in Lyon. To a large extent, it resulted from active cooperation between the Rockefeller Foundation and individual actors within the Lyonnais health system.

Evidently, this process could be interpreted in terms of Americanization, imperialism and the unilateral propagation of a cultural model: the suggestion would then be that the Foundation, placed in a dominant position by its vast financial resources, linked its support to the retention of technical and ideological control over the project. One might also stress the way in which the Lyonnais recipients, whose status as applicants would have put them in the weaker position, put up a certain 'resistance' to the introduction of principles, categories and instruments emanating from across the Atlantic, by attempting to deflect them from their objective. However, if there was a solid messianic ambition on the part of the Americans, the specifics of this ambition were far from clear to them; whereas the applicants on their side knew how to adapt their pitch, how to raise the bidding and, finally, how to pursue their own project by weaving it together with that of the donors. The nature of the undertaking in public heath at Lyon, in common no doubt with other philanthropic operations, cannot be grasped in terms of merely adjusting the need for aid to the supply, nor by postulating an imperialist undertaking, which would be accepted, rejected or deflected. These dimensions were important, but to centre the analysis on them amounts to assuming that philanthropic action works as an exogenous factor in the recipient milieu. This perspective puts too much emphasis on the donor, and thus on the 'American side' of the analysis. The historiography of the international activity of the great philanthropic foundations has been dominated by questions that are central to the construction of the American political community. ${ }^{3}$ For a long time the debate has opposed, on the one hand, a Gramscian point of view that reveals the role of philanthropic foundations in the American capitalist and imperialist world-strategy; and, on the other, a liberal point of view stressing their progressive role as forces for social change in the United States and elsewhere. ${ }^{4}$ More recently, partly as a consequence of the interest taken in the history of philanthropy by non-American researchers, the donor-centred story and problematic has given way to a relational approach which attempts to grasp the material and symbolic transactions between givers

\footnotetext{
${ }^{2}$ P. Bourdelais, ed., Les Hygiénistes: enjeux, modèles et pratiques (XVIII $-X X^{e}$ siècles) (Paris, 2001).

3 P. D. Hall, 'Resolving the dilemmas of democratic governance. The historical development of trusteeship in America, 1663-1996', in Philantbropic Foundations. New Scholarship, New Possibilities, ed. E. Condliffe (Bloomington, IN, 1999); B. D. Karl and S. N. Katz, 'The American private philanthropic Foundation and the public sphere, 1890-1930', Minerva, 19 (1980), 248-59.

${ }^{4}$ For a presentation of this debate and a bibliography: L. Tournès, 'La fondation Rockefeller et la naissance de l'universalisme philanthropique américain', Critique Internationale, 35 (2007), 173-97.
} 
and recipients and to locate these within a larger landscape which shapes the content of these transactions. ${ }^{5}$ Relations of domination are not absent from these transactions-far from it-but their impact needs to be apprehended in the light of the complex diverse contexts in which philanthropic operations develop. A Gramscian interpretation of the politics of foundations, highly relevant though it remains, needs to be refined if it is to represent adequately the full range of results produced by philanthropic action on the ground, its characteristic uneven and exploratory progress and the way beneficiaries contributed throughout to the definition of programmes and grants.

Studying the operations that unfolded in Lyon between the two world wars makes it possible to develop this relational approach, which explores the transactions between donor and recipient. Indeed, what we find is that the projects realized by the Rockefeller Foundation were co-produced with local participants from the various spheres of public health, especially from Lyonnais industrial dynasties. We also find that it is irrelevant to categorize the kinds of people involved as 'Rockefellers' and 'Lyonnais' and that an analysis in terms of a Franco-American confrontation ignores other divides, equally significant. Throughout the negotiations which were to end in the construction of the Ecole d'Infirmières and the Faculté de Médecine, the 'national' dividing line separating the American foundation from its French partners was in fact exploited, rejected or shifted along equally important lines that ran through the Rockefeller Foundation itself (between its departments and hierarchical levels), as well as between the French recipients. These aspects cannot be taken into account by an analysis that deals with the issue as a confrontation between 'American' positions on the one side and 'French' or Lyonnais positions on the other. Nor does such an analysis take account of the history of the trajectories, resources and perceptions at play in these operations. Indeed, this much was evident from the first contacts between our protagonists, during the First World War.

The conflict that broke out in August 1914 marked an important stage in the broadening horizons of American philanthropy. Europe was on the receiving end of American benevolence, with individual initiatives operating side by side with big organizations such as the American Red Cross (ARC), the Rockefeller Foundation and the Salvation Army-not forgetting the creation of structures for coordinating fund raising and the transport of foodstuffs and clothes (the Commission for Relief in Belgium) or interventions in specific fields. In a study of the American Committee for Devastated Regions in the North and East, the authors estimate at 75 the number of charitable efforts created in the

\footnotetext{
5 For example: A.-E. Birn, Marriage of Convenience: Rockefeller International Health and Revolutionary Mexico (Rochester, NY, 2006); S. Amrith, Decolonizing International Health: India and Southeast Asia, 1930-65 (Basingstoke, 2007).
} 
United States to support the French, plus some 50 in France itself; and this as early as $1915 .^{6}$ Most of these organizations were concerned with urgent relief, but some also tried to tackle problems of sanitation, in a structural and preventative way. This was especially the case with the ARC and the Rockefeller Foundation. ${ }^{7}$ Even before the end of 1914, the latter set up a War Relief Commission and, three years later, a Commission for the Prevention of Tuberculosis in France. ${ }^{8}$ It arrived in France in July 1917 to conduct a large-scale prophylactic campaign aimed at curtailing an illness that was endemic in France at the time. These initiatives allied themselves with those of the French hygienic movement in the fight against tuberculosis and the protection of children. ${ }^{9}$ Initiatives launched at the end of the nineteenth century were further boosted after $1914 .{ }^{10}$ From this point of view, the war was a critical juncture when the partners of this joint venture met and identified a common horizon.

Philanthropic activity, especially in terms of bringing help to the sick and poor, formed an integral part of the esprit Lyonnais, the epithet that had defined local identity since the nineteenth century. ${ }^{11}$ The institutions and persons involved in this Lyonnais philanthropy, as well as their rhetoric of 'tradition', found a fertile field of action in the two domains that had been opened up or reactivated by the war: help to the wounded or displaced and the fight against tuberculosis. The industrial and financial grande bourgeoisie was heavily involved in both those sectors. ${ }^{12}$ This was the case with the Gillet family, the great local textile-dyeing dynasty, among others. Léonie Motte-Gillet became involved in running the Société de Secours aux Blessés militaires (the Society for assisting the war-wounded), managing one of the French societies of the Red Cross and organizing auxiliary hospitals in Lyon. ${ }^{13}$ In 1917 she also established the Secours aux Rapatriés (Help for refugees), which looked after children. In addition to her personal commitment, she was able to draw on the connections and resources of the Gillet family and firm for her activities. The Gillet family had patronized associations fighting tuberculosis since the end of

${ }^{6}$ E. Diebolt and J.-P. Laurent, Anne Morgan: une américaine en Soissonnais (1917-1952). De l'Aisne dévastée à l'action sociale (Soissons, 1990).

7 A contemporary view of this action is provided by A. de Rochebrune, La Croisade de l'A. $R$. C. (Paris, 1919).

8 J. Farley, To Cast out Disease: A History of the International Health Division of the Rockefeller Foundation, 1913-1951 (Oxford, 2004), pp. 44-58.

9 L. Murard and P. Zylberman, L'Hygiène dans la République: la santé publique en France, ou l'utopie contrariée, 1870-1918 (Paris, 1996), chs 18 and 19.

10 C. Rollet-Echalier, La Politique à l'égard de la petite enfance sous la III'République (Paris, 1990), pp. 17-41; D. Dessertine and O. Faure, Combattre la tuberculose (Lyon, 1988).

11 P.-Y. Saunier, L'Esprit lyonnais $X I X^{e}-X X^{e}$ siècles: Genèse d'une représentation sociale (Paris, 1995), chs 1 and 2 .

12 B. Angleraud and C. Pellissier, Les Dynasties lyonnaises: des Morin-Pons aux Mérieux du XIX'eiècle à nos jours (Paris, 2003), part 2.

13 Léonie Motte (1884-1965), who came from one of the great textile families in northern France, married Edmond Gillet in 1903. From 1918 onwards, she was one of the leading figures in social and sanitary activities, at Lyon (Gillet Enterprises and the Fondation Franco-Américaine pour l'Enfance), then in Paris (Office de Protection de la Maternité et de l'Enfance de la Seine, French Red Cross and Maison des Oeuvres). 
the nineteenth century. In this capacity, they took part in the initiatives that arose in the wake of the Léon Bourgeois law, which, in April 1916, made it obligatory for every French department to provide a free anti-tuberculosis clinic. Indeed, Lyon was one of several towns that did not await the legislative command. Professor Jules Courmont-a tutelary figure in the struggle against tuberculosis at Lyon - had already created a free clinic in 1905, with the help of the Gillet family in particular. At Lyon, the philanthropic emissaries from America encountered a team of people already seriously involved in the health domain.

The ground was all the more fertile for the fact that the action of American philanthropy was not unknown to the leaders of public health in Lyon. Several medical men were aware of the Rockefeller family's generosity in the area of medical research, particularly those who had remained in contact with their friend Alexis Carrel, winner of the Nobel Prize for medicine in 1912, who had been working in the Rockefeller Institute for Medical Research since 1906. His close friend from student days, Jean Lépine (1876-1967), a professor in the medical faculty, saw him every summer; his colleagues, René Leriche and Georges Mourriquand, had visited him in the United States in 1913; Paul Courmont, the brother of Jules and like him a professor in the medical faculty, also paid a visit in 1908 on the occasion of the Washington Tuberculosis Congress. A number of French businessmen also knew the North American continent. ${ }^{14}$ Edmond Gillet was among those who had spent a year in New York on his initiatory Grand Tour as an industrial heir (1894-95). ${ }^{15}$ This liberal Catholic, who would venture his father's dyeing firm into the great project of chemical industry, revisited the country with his wife, Léonie Motte-Gillet, in 1907 and 1908. ${ }^{16}$

Moreover, before the war there existed a common language of public health that facilitated the encounter between the two contingents. This language was in part the outcome of transatlantic conversations that had thrived in the last decades of the nineteenth century and generated discussions about ideas, methods, techniques, statistics and institutions. ${ }^{17}$ Admittedly, these conversations encompassed both agreements and disagreements, but these were common among American, French and other national hygienist communities-for instance, the project of preventive social medicine shared by a certain number of Lyon doctors, Lépine and Courmont among them, as well as by Lyon notables mobilized in the fight against tuberculosis since the early 1900s. The preventive outlook was also the spine of the action of the Rockefeller Foundation in the

14 Angleraud and Pelissier, Les Dynasties lyonnaises, pp. 269-73.

15 L. Gillet, Vos grand-pères, François, Joseph et Edmond Gillet (Paris, 1961), pp. 83-4.

16 Unlike the doctors mentioned above, the Gillets spoke fluent English. The couple maintained a number of personal contacts with the United States. Léonie Motte-Gillet welcomed numerous young American women to her home and founded the first golf course in the region in 1919.

17 A. Rasmussen, 'L'hygiène en congrès (1852-1912): circulations et configurations internationales', in Bourdelais, Les Hygiénistes, pp. 213-39. 
field of public health and likewise the action of the ARC (over and above its emergency work), whence the place in these two organizations of such wellknown figures in American tuberculosis work and preventive medicine as William Welch and Hermann Biggs. The educational work, the clinics, the follow-up at home with a health visitor (male or female) and the statistical registering of patients-all this constituted a shared grammar of action for health services among the Lyonnais and their American partners. Consider furthermore the question of nursing staff, which some administrators and doctors of the Hospices Civils de Lyon considered in terms close to those applied to US nurses, implying the feminization of secondary hospital staff who would be given specialized vocational training. ${ }^{18}$ Lastly, the Gillets and the Rockefellers shared principles of social action based on the well-understood advantages of such disinterested activities. They perceived their initiatives in the domain of health as being at once an aspect of social and religious noblesse oblige, an instrument of social peace and a tool for the management of industrial labour. It was because they rested on these prior exchanges that the mental frameworks of our protagonists were mutually compatible. These shared outlooks would facilitate their meetings and make it possible, over the years that followed, to overcome personal and institutional rivalries, as well as the vagaries of Franco-American diplomatic relations (especially over the question of war reparations).

The first American organization to establish contacts with the people in Lyon was the ARC. The moment he arrived, Professor William P. Lucas, head of ARC's new Infant Welfare Unit, undertook a tour of France in order to identify places where the Unit could deploy its programme of care and prevention (convalescent hospitals for repatriated children and campaigns of education in pre- and postnatal care). ${ }^{19}$ Lucas was in Lyon at the beginning of September 1917, looking for a hospital to house children who had been repatriated convalescent and who, after a transit via Switzerland, were flocking to France at the rate of two trainloads a day. Doctor Jean Lépine, as member of the Governing Body of the Hospices Civils de Lyon, provided him with the premises he had hoped for and put him in touch with Léonie Motte-Gillet who, for her part, had begun to organize the reception of the repatriated children. Following that first successful exercise, the Children's Bureau-successor to the Infant Welfare Unit-launched a campaign against infant mortality in Lyon during the winter of 1917-18, a pilot project with which Lyon started a trend. ${ }^{20}$ It unfolded along three lines: a major educational exhibition which took place in April 1918 on the main square of the city; the creation, under the supervision of an American nurse, of a squad of 'visiteuses d'enfants' (female child visitors) to observe the health of mothers

18 S. Reverby, Ordered to Care: The Dilemma of American Nursing 1850-1945 (Cambridge, 1987); K. Schultheiss, Bodies and Souls: Politics and the Professionalization of Nursing in France 1880-1922 (Cambridge, MA, 2001), esp. ch. 2. Hospices Civils was a private-public agency that managed the hospital system in Lyon.

19 J. R. Lucas, The Children of France and the Red Cross (New York, NY, 1918).

20 Similar enterprises were put into place at Bordeaux, Toulouse, Marseille and Saint-Etienne. 
and babies in the home and the coordination of various Lyonnais charitable schemes for the protection of children. Lépine helped with mobilizing the medical specialists and institutions around these themes. He obtained the sponsorship of the Hospices for the whole project, which included making their medical staff available for training children visitors. Among them was Lépine himself, but also the doctors Mourriquand and Chatin, a former professor at the Ecole d'Infirmières des Hospices and a cousin of Léonie Motte-Gillet. The latter mobilized her own network of personal and family charities behind the project, urging the other private organizations for children's welfare to coordinate their activities. At the same time, the ARC was developing a frontal attack on tuberculosis. Until then only a handful of visiting nurses had been trained in Lyon by Jules Courmont, and they operated out of his only clinic. The support of the ARC made it possible to upgrade this organization. In 1917 it supplied the equipment and staff for a second clinic, and then its financial support enabled the Comité départemental d'assistance aux réformés tuberculeux and the Institut bactériologique de Lyon to open four new clinics in 1918 and 1919.

It was in connection with the issue of the protection of children that a strong bond came to be formed between the ARC and its Lyonnais partners. From the autumn of 1918, the ARC was preparing to withdraw from French territory and considered leaving a permanent undertaking behind. The battle against infant mortality, in Lyon and elsewhere, was at the heart of its concerns. ${ }^{21}$ The project which the Red Cross had in mind for Lyon included continuing the effort put into training children's visitors, stepping up the work done by clinics, the creation of a Children's Bureau charged with coordinating private and public schemes, the universalization of district nursing, the development of propaganda work and the creation of children's hospitals. ${ }^{22}$ After having conferred with Lépine and Léonie Motte-Gillet, Lucas promised a gift of at least 200,000 francs, with up to one million francs promised to match sums generated by local initiative. The matter was conducted briskly: in December 1918 an organizing committee was set up, bringing together the Protestant bank, Catholic industry, medical and business men. The Lyon subscription was closed on 11 February 1919 at a total of 820,000 francs. On 28 February a big public meeting took place in the Lyon Chamber of Commerce to lay out the bases of a 'Fondation Franco-Américaine pour l'Enfance à Lyon'. 23 The Foundation's administrative council held its first meeting on 16 April. At every stage in these developments, Lépine and the Gillet family brought their social and financial resources to bear. The Gillets were present in the organizing committee and contributed a substantial proportion of the subscription funds; doctors Chatin

\footnotetext{
21 Thus at Paris, the newly created Ecole de Puériculture de la Faculté de Médecine de Paris, which opened in Jan. 1920, emanated from its gift of one million francs.

22 Several of the original documents are reprinted in A. Croze and D. Cigalier, Les Hospices Civils de Lyon de 1900 à 1925 (Lyon, 1927).

23 The formula was frequently employed immediately after the war when certain American undertakings were perpetuated, notably sanatoria and hospitals.
} 
and Lépine organized the public meetings and working parties; Léonie MotteGillet worked to harness the private charitable foundations. All three played leading roles in the new Foundation. Lépine, nominally the vice-president, was de facto president, while Chatin acted as medical director and Léonie MotteGillet directed the Comité de Dames, which coordinated work in the field. ${ }^{24}$ This was the first step of our philanthropic joint venture.

While the protection of children was conducive to cooperation beyond wartime, the tuberculosis front had a different outcome. The ARC simply left this issue in the hands of the Rockefeller Foundation's Commission for the Prevention of Tuberculosis in France ('the Commission'). At the beginning of 1918, this Commission, which had noted during its preliminary investigations that Lyon was the site of one of the first anti-tubercular clinics in France, had financed courses for training female health visitors destined to practise in the new clinics. These were organized under the auspices of the Comité départemental d'assistance aux réformés tuberculeux, but support in Lyon was poor when compared with other cities. Only 18 scholarships were awarded in Lyon between 1918 and 1920, as against 23 in Nantes, 30 in Lille and 117 at the Ecole de la Glacière in Paris, while nothing in Lyon was comparable to the in-depth venture launched by the Commission in several pilot departments. From the beginning, the Commission's staff noted Paul Courmont's desire to retain control over the fight against tuberculosis, particularly over the training of female health visitors (Paul was the brother and successor of Jules Courmont). The relationship was so strained that, in November 1920, the director of the Commission recommended discontinuing scholarships for student health visitors in Lyon because the training centre in Lyon 'has not been managed in accordance with the standard set by the commission'. ${ }^{25}$ This was a poor start to a long-term relationship.

Shortly after the Armistice it was decided that the Commission for the Prevention of Tuberculosis in France would cease its activities in 1922, following the gradual transfer of its workers and programmes to French institutions, public and private. In parallel, the leading lights in the Rockefeller Foundation mooted a means of extending the Foundation's action in France and Europe. They studied the possibilities for action in several domains, foremost among which was public health. It was in this context that a specific programme of nursing education took shape in Europe and particularly in France.

24 Until the moment it disappeared with the restructuring of social insurance and family allowances at the end of the $1940 \mathrm{~s}$, the Foundation had been the principal provider of social assistance and health protection in the children's sector, to the benefit of public administration and private insurance funds. During much of this time, its activities were conducted in close association with the provision of preventive medicine at the Gillet factories. Jean Lépine remained its president until 1946. For a synoptic account of the situation at that point in time: A[rchives des] H[ospices] C[ivils de] L[yon] L168, 'Associations-Fondation Franco-Américaine'.

25 R[ockefeller] A[rchives] C[enter], New York, RF 1.1/500C/10/105, International Health Board Minutes, 24 Dec. 1920. 
The investment of the Foundation in nursing education in Lyon was the result of four simultaneous developments: the initiative of the heads of the Commission and of the woman responsible for nursing education within the Commission, namely Frances Elisabeth Crowell; the study of nursing education in the United States and Europe, launched by the management of the Rockefeller Foundation at the instigation of professional nursing and medical milieux in the United States; the frontier battles waged between organizations and 'barons' within Rockefeller philanthropy; and finally the demands and proposals emanating from public health activists in Lyon. All this was somewhat removed from the elaboration, behind the closed doors of the Foundation's Board of Trustees, of an exact export model.

In the development of the Rockefeller programme, the initiatives undertaken by Elisabeth Crowell are especially remarkable. ${ }^{26}$ When in charge of the Commission's Bureau of Public Health Visiting, she set up courses for the female 'health visitors' who were needed to staff the new clinics. The Commission created or supported such schools in various French towns and cities, contributing to their general budgets and granting scholarships to their pupils. From this anti-tuberculosis basis, she envisaged the possibility of contributing to the professionalization of nursing work in France: her memos suggest that from 1919 she intended to throw herself into a general study of nurses' training. ${ }^{27}$ Her perspective was at once sanitary (developing the frameworks for social hygiene), technical (enhancing the level of competence of nurses), social (shifting the recruitment of nurses towards educated women) and emancipatory (giving educated women opportunities for personal and career development). The International Health Board, being eager to close the Commission's programme, did not follow this up, any more than did the Rockefeller Foundation at the outset. The latter was concerned with a study of nursing education in the United States. ${ }^{28}$ This had just materialized in December 1918 with the creation of a Committee for the Study of Public Health Nursing Education; the Foundation awaited its results because part of its work related to Europe. ${ }^{29}$ Thus developments on the Continent and in the United States were interrelated from the start. While awaiting the report's conclusions, all decisions were suspended

\footnotetext{
26 Frances Elisabeth Crowell (1874-1950) was a trained nurse and a collaborator of Livingston Farrand at the Association of Tuberculosis Clinics in New York City, where she was responsible for the creation of dispensaries and the training of visiting nurses; she was recruited by the Commission for the Prevention of Tuberculosis in France. E. D. Vickers, 'Frances Elisabeth Crowell and the politics of nursing in Czechoslovakia after the First World War', Nurs Hist R, 7 (1999), 67-96.

27 RF 1.1/500C/9/97, Embree to Williams, 23 Sept. 1919; RF 1.1/500C/10/108, Memorandum on training schools for public health visitors in France, 1920.

28 Since 1914 the Foundation had been called upon to support the establishment of standards for public health nursing education or to undertake a general study of nursing schools that would prompt developments comparable to those which had been achieved in the medical schools following the report by Abraham Flexner.

29 RF 1.1/200/121/1494, Winslow to Vincent, 11 Mar. 1919. In the end, the European part of the survey was not carried out.
} 
and Crowell sent her memos in vain. It was not until 1920, when it became clear that the report would not be available for some time, that the Foundation envisaged a separate initiative, in view of the dramatic sanitary situation in Europe. ${ }^{30}$ It should not be forgotten that this was the middle of the typhus epidemic in Eastern Europe. Sent to Europe between June and October 1920, the secretary of the Foundation, Edwin Embree, was charged with studying the opportunities for developing a nursing programme. He departed after having gleaned the opinions of the leaders of the American nursing community and members of the Committee for the Study of Public Health Nursing Education, which he would test in Europe. His report concluded that there was both a need and a demand for professionalization of nurses' work (in both its branches: bedside and public health nursing) through an educational programme in line with the standards of modern medicine. This would aim to train nurses in specific skills at specialized schools, over a period of about two and a half years. ${ }^{31}$ On his return, the idea of an endeavour in the field of nursing education was accepted in principle and he was authorized to set up projects for Europe and the United States. ${ }^{32}$ Elisabeth Crowell was finally charged with the European side of the project in February 1921, not without some hesitation.

At this point in time, various components in the Rockefeller philanthropic galaxy had already undertaken action in the nursing field in several parts of the world-but without any coherence. Within the framework of the Peking Union Medical College (China), the Foundation itself had developed a highly specialized teaching programme for hospital nurses, based on several years of training. ${ }^{33}$ Meanwhile, as we have seen, the Commission for the Prevention of Tuberculosis had set up short training programmes (ten months) in France, with the aim of hastily supplying the anti-tubercular clinics with health visitors. In 1921 the International Health Board appointed nurse Ethel Parsons to create a course for health visitors in Rio de Janeiro, which it financed within the terms of an agreement with the Brazilian government. The harmonization of these multiple undertakings was de facto one of the issues implicitly at stake for the proponents of the new nursing programme in the early 1920s. Yet, without any declaration of general policy and on an ambiguous organizational basis, initiatives were redoubled between 1922 and 1924, in both Europe and the United States, under the aegis of Crowell and Embree, the latter making nursing one of his pet projects within the Foundation.

While France was from the start one of the countries to be involved in a possible European initiative, the prospective memos of Crowell singled out Paul

30 The 'Goldmark Report', named after the famous individual responsible for the research, Josephine Goldmark, was published in 1923 as Nursing and Nursing Education in the United States. Report of the Committee for the Study of Nursing Education (New York, NY, 1923).

31 RF 3.1/900/9/75, RF History source material, vol. 9, p. 2208.

32 RF 1.1/700/19/137, Executive Committee meeting, 26 Oct. 1920.

33 M. B. Bullock, An American Transplant: The Rockefeller Foundation and Peking Union Medical College (Berkeley, CA, 1980). 
Courmont and his low-grade training school for public health visitors very negatively, as 'purely a one-man affair' ${ }^{34}$ Embree's European tour, during the summer of 1920, did not include Lyon. The situation altered after the beginning of 1921 when Crowell visited schools throughout France, in order to estimate the chances of developing nurses' education. The Strasbourg school seemed the most promising to her, but Lyon had potential since it possessed, as did Nancy, three specialized nursing schools which it might be possible to merge into one. ${ }^{35}$ The dominant position of Paul Courmont, however, seemed to blight her every hope, and it was elsewhere in France that she pursued her first initiatives. Following the creation of the Brevet d'Etat d'Infirmière (National Certificate of Nursing) in June 1922, a decision by local public authorities changed the situation: the conseil général of the department of the Rhône and the municipal council of Lyon now asked the three schools to merge in order to pool their financial aid. ${ }^{36}$ In the face of the refusal of the parties involved, with Courmont resisting the merger, it was Crowell who resolved the confrontation with some lethal tactics which she deployed during a visit to Lyon, in November 1922-just as Courmont's health visitors school found itself in a difficult financial situation. Her idea, following the general principles she had sketched out since 1919 and which matched the fledgling guidelines of the Foundation's nursing activities, was to create a unified school providing three strands of training: for hospital nurses, children's visitors and health visitors for tubercular patients. Her proposal placed the school under the sponsorship of the Hospices Civils and the direction of the Faculty of Medicine. ${ }^{37}$ This was possible because Crowell relied on the support of Jean Lépine and Léonie Motte-Gillet, heads of the Franco-American Foundation that ran the school of children visitors. Both of them had been interested in the training of nurses since the turn of the century. ${ }^{38}$ Lépine was dean of the faculty, president of the Franco-American Foundation and a member of the governing body of the Hospices Civils; he was the man to pull the ropes, and his role in this whole plan of action was crucial. Crowell promised him a donation of 100,000 francs to finance equipment and teachers' salaries in the new school, as well as subsequent support from the Rockefeller Foundation to carry on the school's activities. Immediately after receiving the cheque and the letter specifying the conditions of the Foundation's aid, Lépine called a meeting at the beginning of December 1922 and pushed the matter through. Strengthened by Rockefeller support, he was chosen to preside over

\footnotetext{
${ }^{34}$ RF 1.1/500C/10/108, Memorandum on training schools for public health visitors in France, 1920.

35 RF 1.1/500/9/100, Nursing education and hospital services in France, 1920. These were the children's visitors, the health visitors and the school of hospital nurses created in 1899 by the Hospices Civils de Lyon.

36 A[rchives] D[épartementales du] R[hône] T659, Session du Conseil Général, 30 Aug. 1922. Edouard Herriot, the mayor of Lyon, already expressed his support for a secular, regional school of nursing in 1906.

37 RF 5.2/145/1915, Memorandum Crowell, 20 Nov. 1922; Gunn to Rose, 20 Nov. 1922.

38 Léonie Motte-Gillet had supported nursing training by the Croix Rouge since 1905.
} 
the provisional bureau which worked on elaborating the statutes and launching the school at the resumption of the academic year in 1923.39

This stage of the constructive process set in full motion the cooperation between Crowell, Lépine and Motte-Gillet over the organization and content of the teaching. In July 1923, the process was crowned by the appointment of a director in the person of Hélène Mugnier, a former nurse in one of the Commission's clinics who had been receiving additional training since July 1922 at University College London Hospital thanks to a Rockefeller Foundation fellowship. ${ }^{40}$ Every member of the coalition provided support: the initial financing of the School came from the Foundation and the Lyonnais philanthropic networks (donations from the Caisse d'Epargne and the Franco-American Foundation, besides a personal donation from Mme Gillet). Relations between the partners at that time were characterized by deference and tact. Crowell who, from February 1923, had set in motion her idea to have the new school placed under the headship of Mugnier, cunningly developed her strategy of persuasion, taking Léonie Motte-Gillet to London to show her the English hospitals and meet the female French fellows. ${ }^{41}$ On their side, Lépine and MotteGillet consulted Crowell unfailingly on important decisions, receiving her in Lyon and visiting her in Paris, and consistently involved Americans in the activities of the school during their visits. When the European nursing programme was officially approved by the Foundation in December 1923 (after another grand tour across the Continent by Embree and Crowell), the Ecole d'Infirmières et de Visiteuses de Lyon et du Sud-Est had been open for two months. As an early success, it became one of the strategic hubs around which Embree and Crowell strived to change the conception, practice and perception of the profession of nursing in Europe.

The injections of financial aid from the Foundation, which were staggered over the period 1922-38, albeit with concentrated input during the decade 1923-33, ranged from a grant for the construction of a new building (completed in 1933) to fellowships for post-graduate training (seventeen for the educational and managerial staff of the Ecole d'Infirmières). It included study visits abroad (to the United States, Canada, Hungary, Poland and the United Kingdom), as well as the financing of equipment (boarding facilities, demonstration rooms, a

39 A[rchives de l'] E[cole] R[ockefeller], Lyon, dossier 'Reconnaissance d'utilité publique. Création de l'Ecole'.

${ }^{40}$ RF 1.1/700/19/137, Crowell to Vincent, 27 Aug. 1922. The dispatch of Mugnier and five other French nurses to London in 1922 was a result of Crowell's idea that the nursing schools should be furnished with French teaching and directorial staff, once imbued with the values incarnated by British or North American professional practice. The object was to implant these values at the heart of the schools and hospital services, but appropriated by French nurses, rather than being delivered by British or American ones. For Crowell, this was not so much a concern for better nursing techniques as a fundamentally different concept of caring for the sick with regard to health, well-being and diet and its translation into the professional spirit of nursing.

41 RF 1.1/700/19/137, Crowell to Embree, 12 Apr. 1923. 
diet kitchen, school services in hospital wards and a clinic). ${ }^{42}$ They also covered salaries for the school's management and emergency financial assistance to make up for budgetary deficits. This support was of the utmost importance. Until 1934 the Foundation would in fact make substantial financial backing available to the school, contributing each year a share equivalent to at least 40 per cent of the school's income. ${ }^{43}$ This was a crucial contribution considering the absence of regular support from the national and local public authorities.

Apart from this financial support, it was in everyday action that close links were forged between Crowell and her female collaborators (American, Canadian, English and French) on one hand and the school staff on the other hand. This close association was developed through regular correspondence, shared observation tours and numerous visits exchanged between Paris and Lyon. If the nurses of the Foundation's Paris office were the eyes and ears of the Rockefeller Foundation within the school, they were also professionals who shared the concerns of their Lyonnais colleagues. Their role was both technical and human: they visited the Lyonnais fellows at their places of study; sent the Lyon directors and instructors documentation about American, Hungarian, Polish, Bulgarian and Brazilian schools; travelled with them to foreign destinations; wrote to keep up with the news; regularly invited people to their Parisian office and homes; and they regularly came to Lyon for several days in order to meet Lépine and Motte-Gillet and also to work with the managerial and teaching staff. This work was important and required meticulous care. Crowell concerned herself with positioning burners on the new diet kitchen, no less than with plans for the new building, which she studied regularly with Lépine, the administrative committee of the school and the architect. Her collaborator, Hazel Goff, spent several weeks at the school in 1929, standing in for the director, who had been taken ill. She revamped the teaching of nursing and medical theory during her stint. Another of Crowell's assistants, Mary Tennant, remained on site for whole weeks, in order to set up the school's clinic. All these women were regularly present at examination sittings for the Diplôme d'Etat; they were ceaselessly in communication with students, instructors, directors and members of the governing body of the school.

However, while this collusion united officers and beneficiaries in the implementation of a programme whose efficacy they all wanted to demonstrate to the Foundation's Board of Trustees (the officers wanted to underline the cogency of their initiatives, the beneficiaries wanted to have their grant

42 In France, substantial financial assistance was initially granted to other former centres for training health visitors, under the same condition that combined schools should be created (in 1922 at Nancy or at Nantes in 1925). The Ecole at Lyon was the only one in France to receive a later, substantial sum, though the Foundation financed the Bureau Central des Infirmières at the Ministry of Health and Crowell maintained permanent links with the whole French nursing world until the outbreak of the Second World War.

43 RF, Minutes, 27 Feb. 1927; RF 1.1/500C/10/105, Formulaire d'attribution de bourse, 19 June 1934; AER, Livre de comptes. 
renewed), it did not prevent differences of opinion and conflicts. One of the most striking disagreements here was an implicit but basic misunderstanding over the Lyon nursing programme. A certain number of Lyonnais doctors, including Lépine, did share the training principles of the Rockefeller Foundation, which for the most part adopted the priorities of those American nurses who had been involved in the production of the report from the Goldmark Committee. Yet, for all that, they did not subscribe to its feminist corollary, which considered the nursing profession as one of the professional domains that women could exploit in the interests of their social emancipation. The nursing officers of the Foundation, and above all Crowell (despite being far removed from what she called the 'crystallized feminism' of some leading American nurses), were very anxious to enable the leaders of European nurses to acquire professional expertise, financial autonomy and decision-making power. Once the Nursing School was established, Crowell and her female collaborators worked tirelessly to outline an independent realm for its first director, Hélène Mugnier, constantly impressing on the members of the Conseil d'Administration her competence as nurse, manager and decision maker. This endeavour, which was reflected in, among other things, the high salary paid to the director of the School $(12,000$ francs a year in 1923, which was 2000 francs more than a part-time lecturer in the Faculté de Médecine holding an agrégation), ran up against gender, social and academic hierarchies in Lyon. Mugnier was reined in by the Conseil d'Administration and not least by its Comité des Dames. Dominated by the figure of Léonie Motte-Gillet, flanked by Mme Mouisset (who had been a leader in the anti-tubercular movement since 1910), this committee met every week to handle the details of internal management, with a high hand on the admission of students and the granting of scholarships. Even weightier was the supervision of Dean Lépine, president of the Conseil, whose multiple offices (at the School, Hospices Civils and Faculty of Medicine) enabled him to intervene in every domain from the selection of teaching staff to the organization of school services and through practical education in the hospital wards. While Crowell tried to carve out an autonomous space for the first director of the School, the latter was constantly blocked by Lépine who, in the end, obtained her resignation in 1929-just as he would that of Mademoiselle Roberti, a later directrice, in 1938. ${ }^{44}$ To this should be added the regular departure of female instructors [monitrices], damned for their independent-mindedness, or insubordination, as Lépine saw it. As a champion of the interests of certificated nurses or 'elite personnel', Lépine's view of nurses was essentially that they were competent

\footnotetext{
44 This resulted, notably, in the maintenance of a reduced teaching and administrative staff, the absence of a house rule specifying the roles and prerogatives of each post, Lépine's resistance to the appointment of a technical committee of nurses to advise and support the directrice and, moreover, his frequent refusal to delegate decision-making to her. A good example is to be found in RF 12.1, Crowell's diary for Aug. 1928.
} 
assistants, subordinated to the doctors. ${ }^{45}$ He seemed convinced that no woman could fulfil a managerial role in the male world of hospitals and medicine. ${ }^{46}$ Whereas Crowell had made an alliance with Lépine against Courmont in 1922, she found herself, both as a nurse and a woman, ever more at loggerheads with the man she accused of making the position of women directors 'untenable' because of his demands for a submissive attitude on the part of the all-women school's pedagogical team. ${ }^{47}$ The breach became permanent after 1938, following the dismissal of the directrice and the appointment by Lépine of a successor holding no nursing qualification. The school was firmly on its feet, but it never attained the degree of development and autonomy that Crowell had initially hoped for. On the nursing school chapter, the Lyonnais side of the partnership managed to remain in control after discouraging their philanthropic patrons. Nursing matters remained entangled with the Foundation's support for medical research in Lyon, and Lépine's presence at the heart of both was an important reason for this outcome.

\section{I I}

Just after the First World War, the Rockefeller Foundation took on the reorganization of teaching and research in medicine in Europe, encouraging the establishment of medical centres integrating faculties of medicine, hospitals and research laboratories and urging doctors and teachers to break with the liberal practice of medicine in favour of medical research. This was a programme that had been sketched out in Abraham Flexner's two weighty reports: Medical Education in the United States (1910) and Medical Education in Europe (1912). ${ }^{48}$ The General Education Board, another element in the Rockefeller set-up, started implementing these objectives through selective financial aid to certain universities on the east coast of the United States. It was in the wake of this first step that the Division of Medical Education was created in 1919 within the Rockefeller Foundation itself, with a brief to push the programme beyond the United States. ${ }^{49}$ Many Lyonnais teachers and doctors were familiar with this

45 This view was also held by some of the 'medical barons' at the Rockefeller Foundation, such as Wickliffe Rose and Frederick Russell.

46 HCL 1 LP 327, Comptes rendus sténographiques du Conseil Général des Hospices, 18 Oct. 1933, which reveals his stance against taking on female doctors in a children's hospital at the Hospices Civils de Lyon.

47 RF 1.1/24/272, Crowell to Lépine, 3 Jan. 1938; on how the 'women's question' was carefully kept at bay by male doctors in the field of public health visitors: Dominique Dessertine, 'Infirmières-visiteuses de la lutte antituberculeuse en France 1900-1930', Bulletin du Centre Pierre Léon (1995), p. 62.

48 T. N. Bonner, Becoming a Physician: Medical Education in Britain, France, Germany and the United States, 1750-1945 (New York, NY, 1995); S. Wheatley, The Politics of Philanthropy: Abrabam Flexner and Medical Education (Madison, WI, 1988).

49 W. H. Schneider, 'The men who followed Flexner: Richard Pearce, Alan Gregg and the Rockefeller Foundation medical divisions 1919-1951', in idem, ed., Rockefeller Philanthropy and Modern Biomedicine: International Initiatives from World War 1 to the Cold War, (Bloomington, IN, 2002), pp. 7-60. 
scheme, inspired mainly by the features of some German medical schools, which constituted Flexner's intellectual horizon. ${ }^{50}$ Lépine was a case in point: he was entirely sold on the experimental approach to medicine and hailed his father for having defended single-handedly this outlook in Lyon; he was more at home at the laboratory bench than in the consultation cabinet. Raphaël Lépine had, indeed, studied medicine in Germany and kept in touch with developments across the Rhine. This common intellectual mindset would make the elaboration of a Lyonnais project a lot easier for the Division of Medical Education.

Lyon showed up from 1921 on the radar of the Foundation, at a time when it was attempting to identify sites in Europe that might be favourable to its designs, perhaps following indications given by Alexis Carrel. ${ }^{51}$ The Lyonnais surgeon, René Leriche, records having been invited to the Foundation in the spring of 1921 during a trip to the United States, to say whether or not he would agree to head up the creation of a new Faculty of Medicine in Lyon. ${ }^{52}$ After having explained that a private medical school could not be created out of the blue in France, he directed the attention of the leaders of the Foundation to the opportunity opened up in Lyon by the construction of a new hospital and the presence of an 'active and innovating Dean'. In early 1922 a new Rockefeller emissary was in Europe; this was none other than Abraham Flexner who, on behalf of the General Education Board, was exploring the opportunities for assisting medical research in Europe. ${ }^{53}$ Flexner went to Lyon to visit Leriche, who showed him round the site of the hospital and put him in touch with the 'active and innovative Dean', namely, Jean Lépine.

Lépine seems to have grasped immediately the potential of this first contact, all the more so because he shared the basic tenets of Flexner's general approach. As Dean of the Faculty of Medicine since 1920, Lépine was looking for the means of upgrading the whole institution, at a time when the construction of the Grange Blanche hospital (which was intended to integrate the university clinics) announced a reorganization in the content and form of medical teaching in Lyon. He also knew, from his discussions with Carrel and knowledge of support provided at London and Brussels, that the Rockefeller Foundation had the financial resources to support large-scale projects. Possibly he had also learnt from the experience of the Franco-American Foundation that American support generally went to those who could muster local resources. These elements are clearly expressed in the letters he wrote, immediately after

50 J. F. Picard, La Fondation Rockefeller et la recherche médicale (Paris, 1999), ch. 1; L. Tournès, La Philanthropie américaine et l'Europe: contribution à une bistoire transnationale de l'américanisation, Mémoire d'habilitation à diriger des recherches (Université Paris-I, 2008), ch. 3 .

51 After 1928, Lépine thanked Carrel for his support and advice on this matter, but no mention of Carrel appears in the archival material that has been consulted.

52 R. Leriche, Souvenirs de ma vie morte (Paris, 1956), p. 195.

53 A. Flexner, Medical Education: A Comparative Study (New York, NY, 1925). 
Flexner's visit, to the Fondation Scientifique du Sud-Est, a structure founded in 1917 by the industrialists of Lyon in order to reorganize the Ecole de Chimie de Lyon. ${ }^{54} \mathrm{He}$ asked that the Fondation Scientifique agree to play the role of backer for potential investment by local and private interests and that of intermediary between the Rockefeller Foundation and the Ministry of Public Education, in the event of American financial help for the Faculty of Medicine. ${ }^{55}$ From these initial contacts and at a time when nothing had yet been formulated explicitly, Lépine set about preparing the mobilization of the fledgling Lyonnais scientific philanthropy.

These preliminaries took place in January 1922, before the nursing project got off the ground, but they are connected with it nonetheless. A few months before, in September 1921, the Peking Medical Union College had been inaugurated. Set up on the basis of the Flexner Report and the Johns Hopkins University School of Medicine, it was designed to integrate a faculty of medicine, a hospital and a nursing school. The director of the International Health Board of the Rockefeller Foundation, Wickliffe Rose, considered that the synergy between these three elements should run as a unifying thread through all the action undertaken by the Foundation in support of medical teaching. This mindset had the indirect effect of enhancing the value of the Lyon site, where the three elements were in flux. ${ }^{56}$ This favourable prejudice, of which Embree and Crowell were aware, stimulated their entrepreneurial spirit. They understood, as did their interlocutors Lépine and Motte-Gillet, that the fate of the nursing school was tied up with plans for the Faculty of Medicine and vice versa. The complicity between these four was sealed in 1923, when Embree and Crowell were on a trip to Lyon on the occasion of the inauguration of the nursing school. They broached with Lépine the matter of medical education, despite this not falling within their province at all, and asked him for detailed memos on the situation regarding the Faculty of Medicine. They offered to speak for the Lyon site with the Division of Medical Education whose director, Richard Pearce-a long-serving member of the ARC-would soon be undertaking a large-scale investigation in France. ${ }^{57}$ No doubt this was done in order to generate a favourable dynamic for the nursing project. Lépine supplied them with three memoranda in which, following their advice, he described the situation in Lyon in shrewdly chosen terms. He presented his own trajectory and the dedication of his family to experimental medicine, supplied quantitative

\footnotetext{
54 The Gillets played a vital role in its foundation and it was presided over by Joseph Gillet, fatherin-law of Léonie Motte-Gillet.

55 A[rchives de la] F[aculté de] M[édecine] de Lyon, green untitled dossier, Lépine to the Fondation Scientifique du Sud-Est, 14 Jan. 1922.

56 RF 1.1/500/9/97, Vincent to Williams, 2 Aug. 1921.

57 RF 1.1/500/3/27, Embree diary, RG 12.1; ADR, unclassified dossier, 'Faculté de Médecine. Négociation entre le Doyen et la Fondation Rockefeller: Correspondance'.
} 
data about the faculty and, in his description of the Lyonnais context, he foregrounded the substantial hospital infrastructure, the openness of the university body to the international community and, most importantly, the dynamism of local philanthropy. Finally, he raised the possibility of creating in Lyon 'a complete medical centre', thus complying with a criterion that he was not supposed to know about. ${ }^{58}$ Crowell and Embree dispatched the report to Pearce, promising to exercise their influence on 'the most powerful people', namely the officers of the Foundation. ${ }^{59}$ This collusion was blatant enough for Crowell to reflect on the episode as follows: 'And now I have to pull out of this whole business, and nobody who might come later on behalf of the Foundation must ever know the lowly role I have played in it.' 60

When he began his investigation in 1924 to explore the possibility of financing a medical centre in France, Pearce had already had his attention drawn to the case of Lyon. He met Lépine several times between December 1924 and March 1925, always coming away with a favourable impression. ${ }^{61}$ His final report reiterated the arguments put forward by Lépine in the documents drawn up in 1923 and serious negotiations with the Rockefeller Foundation about financing a new building for the Faculty of Medicine began shortly afterwards, with Lépine being quickly identified as the essential component by the officers of the Foundation and with good reason. The Foundation's support, as defined by Pearce, involved more than the construction of a new building for the faculty. The idea was to use the opportunity of that construction fundamentally to reorganize medical teaching in Lyon, by systematizing the relation of teachers and students with the work of laboratory research and the hospital. ${ }^{62} \mathrm{~A}$ building and educational project of this kind would set in motion all the workings of the University of Lyon, the Hospices Civils, the Parliament, the Ministère de l'Instruction Publique and the French state, which had to come up with an equal share of the finance for the new building. Lépine was able to activate all the necessary connections, thanks to his personal connections, and as a result of his numerous positions of authority: as dean of the faculty, he also sat on the Conseil Général d'Administration des Hospices Civils and on the Comité Supérieur de l'Education which had to vet curriculum changes. Due to the role he and his father had both played in republican and Dreyfusard networks, he was also a long-standing acquaintance of the mayor of Lyon and leading national politician Edouard Herriot. Lépine also knew the members of parliament for Lyon, such as Justin Godart, as well as the rector of the University of Lyon, Jacques Cavalier (who, in 1926, became director for Higher Education at the Ministère de l'Instruction

58 RF 1.1/500/3/27, Lépine to Crowell, 16 Sept. 1923.

59 This was done, as conversation between Vincent, president of the Foundation, and Crowell testifies: RF 12.1, Vincent diary, 29 Apr. 1924

${ }^{60}$ RF 1.1/500/3/27, Crowell to Lépine, 9 Oct. 1923.

61 RF 12.1, Pearce diary, 20 Jan. 1925.

62 RF 1.1/500/3/27, Pearce to Gregg, 28 July 1925. 
Publique, then under the direction of Herriot). Finally, through his uncle, Louis Lépine, the former Prefect of Police for Paris, he controlled a network of relations at the highest level of the French state.

Once again, however, it would be a mistake to suppose that negotiations unfolded by means of a Franco-American face-to-face. Pearce's assistant, doctor Allan Gregg, was from September 1925 Lépine's privileged interlocutor in the realization of the project, having been charged with ensuring that the objectives of the Foundation were observed. ${ }^{63}$ But the role he played turned out to be more ambivalent, as the following episode indicates. Pearce had conceived an 'education' programme for Lépine and his collaborators in the spring of 1925, which included a series of trips to France, Great Britain and the United States. For Pearce, these trips would allow Lyonnais academics a first-hand experience of the best arrangements in laboratories and in the question of integration between teaching and the hospital. ${ }^{64}$ In his instructions to Gregg, Pearce made the actual granting of Foundation money depend on a veritable change of heart, which these pilgrimages were supposed to bring about: 'We may not go further with this. It all depends on whether, after visiting United Kingdom and the United States, they see the light and can visualize a real medical school. ${ }^{65}$ So Lépine left for Great Britain in June 1925. Once back in France he assured the American (with some soft-soaping) that 'my two colleagues and I have returned convinced that your view is the correct one as regards medical teaching and that we would now do well to adapt our teaching to modern needs' ${ }^{66}$ Following this, Lépine baulked at going to the United States and tried to hasten the finalization of the decision by arguing that the agreement over principles was already firmly established. Pearce refused to budge, for he saw in the US trip the key to the 'radical change in the methods of laboratory instruction', which was expected from the Lyon programme. No trip, no money, he stated. ${ }^{67}$ Gregg resolved the situation in the style of a veritable double agent. On 8 September 1925 he visited Lépine in Lyon and gave him the means for untying this Gordian knot. The very next day the latter informed the Ministry of Education of the conversation and the Ministry set about drawing up an official application for finance from the Rockefeller Foundation, in order to carry out preliminary studies. ${ }^{68}$ Lépine's letter then distinguished between 'the technical services' of the Foundation 'devoted to our cause, as Gregg's move shows', and the decisionmaking organs of the Foundation, whose state of mind allegedly made even

\footnotetext{
63 On Gregg: W. H. Schneider, 'The model American Foundation officer: Alan Gregg and the Rockefeller Foundation medical divisions', Minerva, 41 (2003), 155-66.

${ }^{64}$ RF 1.1/500/3/27, Pearce to Carter, 20 Jan. 1925.

65 RF 1.1/500/3/27, Pearce to Gregg, 25 May 1925.

66 RF 1.1/500/3/27, Lépine to Pearce, 14 June 1925.

67 RF 1.1/500/3/27, Pearce to Gregg, 28 July 1925.

68 ADR, unclassified dossier, 'Faculté de Médecine. Négociation entre le Doyen et la Fondation Rockefeller: Correspondance, Lépine to Cavalier, 9 Sept. 1925. Gregg pushed his complicity as far as forwarding to Lépine the copy of his letter to Pearce on the subject of his visit to Lyon.
} 
Gregg apprehensive. Lépine issued a reminder that the Executive Committee of the Foundation had invited him to the United States. ${ }^{69} \mathrm{He}$ added that this Committee 'would not understand our making a request before I had accomplished that first rite and had somehow received the schooling and demonstrations that they intend to give me over there in the excellence of their method. So I must be-as it were-touched with grace as a result of this trip, and our proposals must be inspired by it.' Thus released from his tight spot by Gregg, Lépine undertook the trip to the United States in May 1926, at the conclusion of which he informed Pearce of his definitive conversion-much to the satisfaction of the latter, who noted in his diary: 'L[épine] very satisfied with his work in this country. Has obtained a large amount of very valuable knowledge. Sees his way clear to unite School and hospital and he thinks to establish modern laboratory instruction in medical sciences. ${ }^{, 70}$ In other words, this was the case of a transaction where the expectations of one of the partners (Pearce) were accepted in advance by the other (Lépine). Lépine, consequently, could not be affected by the persuasive strategy devised by Pearce, but feigned conversion in order to convince him. It was Gregg who taught Lépine the rules of the game that produced a 'strong case' to be placed before the Foundation trustees; who taught him that by simulating the effectiveness of the programme of 'education' devised by Pearce he could load the dice in his favour. Once the Gregg-Lépine collusion has been identified, it becomes difficult to distinguish, within Lépine's subsequent invocations of the United States, between remarks that may be attributed to his cynical (indeed ironical) verbal displays of 'conversion' and those that reflected an actual adoption of teaching methods, forms of organization and architectural features observed in United Kingdom or in the United States. This encapsulates the whole problem besetting the analysis of donor-recipient relations: both protagonists gave themselves roles to play, which it is important to grasp by multiplying the criss-crossing of sources.

While he was negotiating with the French state on one side and with the Rockefeller Foundation on the other, then while the faculty building was being constructed, Lépine was again able to count on the support of the Gillet family. Edmond Gillet, Léonie's husband, delivered generously: he backed the project in the numerous decision-making bodies on which he sat (the University Council, the Conseil d'Administration des Hospices Civils and the Fondation Scientifique du Sud-Est); through the use of his Parisian connections (in particular with the Minister Loucheur) and, most importantly, his supervision of the technical and financial aspects of the project. This last aspect, sealed in the summer of 1927 during a series of meetings with Gregg and Lépine, was

69 The Executive Committee, comprising trustees and officers, was a body endowed with certain powers of decision in order to get operations under way. It also prepared the biannual meetings of the Foundation's Board of Trustees, where decisions were made regarding the most important appropriations.

${ }^{70}$ RF 12.1, Pearce diary, 13 May 1926. 
especially appreciated by the Foundation, at the very moment when the Board of Trustees was preparing to pronounce on the Lyon dossier. ${ }^{71}$ Edmond Gillet presented his pledge at the very heart of the Rockefeller set-up during a trip to New York in the autumn of 1927 , when a final decision was being made. He promised the leaders of the Rockefeller Foundation and possibly John D. Rockefeller Jr himself that he would ensure that the Fondation Scientifique du Sud-Est (over which he had presided since 1923) assumed responsibility for managing the endowment earmarked for underpinning scientific research in the new faculty. ${ }^{72}$

The rapid progress of the building work owed a great deal to the involvement of Gillet. Ennemond Bizot, a Polytechnic engineer and the son-in-law of Edmond and Léonie, negotiated with the contractors and kept a daily eye on the site, checking in particular the potentially troublesome casting of the reinforced cement. A comptroller from the Gillet factories went through invoices and bills, while the accountancy department saw to their payment. The soil was broken in January 1928 and the new faculty opened its doors at the start of the academic year 1930 without the building credits having been exhausted. ${ }^{73}$ What is more, the Fondation Scientifique du Sud-Est soon received the endowment earmarked for the scientific research to be developed by the faculty, in accordance with the agreement reached between Gillet and the Rockefeller Foundation in 1927. Fundraising plans were made in 1931, under the direct patronage of Edmond Gillet. He died shortly after, but the subscription was inaugurated in 1932 with a payment of 100,000 francs as a legacy from his estate. The Fondation Scientifique, subsequently headed by Edmond's brother, continued to manage this research fund (jealously controlled by Lépine) until the $1940 s^{74}$ This

\footnotetext{
71 ADR, unclassified dossier, 'Faculté de Médecine. Négociation entre le Doyen et la Fondation Rockefeller: Correspondance, 5 Nov. 1927-10 July 1934. Edmond Gillet undertook to take charge of all the practical organization involved in constructing the new faculty. The legal device adopted was that of a construction commission, which acted in the name of a group of benefactors of the University', in order to avoid proceeding to a tendering process on the open market in disbursing the funding supplied by the Foundation. The result was a complex process because part of the funds was supplemented by a state subsidy, which had to be employed using more regular procedures.

${ }^{72}$ A[rchives de la] F[ondation] S[cientifique de Lyon et du sud-est], registre de procès-verbal des séances du Conseil de la Fondation Scientifique, 1917-1939, meeting held on 10 Dec. 1931, report from Paul Gillet; J. Reverdy, Madame Edmond Gillet et son temps 1884-1965 (Paris, 1972), p. 58; ADR, unclassified dossier, 'Faculté de Médecine. Négociation entre le Doyen et la Fondation Rockefeller: Correspondance', speech delivered by Lépine at the Conseil de Faculté on 23 Oct. 1931, to mark Edmond Gillet's death. The Gillet industrial group developed its chemical branch enormously during and after the war and resumed regular relations with du Pont de Nemours in the 1920s (crosspurchase of licences, Edmond's participation in the du pont Board). Edmond's wife accompanied him on certain trips that he took on this account (in 1924 and 1927). On the earlier occasion, she profited from the links that were forged during a former visit of Rockefeller Foundation president George Vincent to Lyon, to obtain from him the necessary recommendations that allowed her to explore the operation of charitable work in New York.

73 An identical financial set-up was initially put in place for the construction of the Ecole d'Infirmières, following the funding accorded by the Rockefeller Foundation and the French state in 1932, with Bizot in charge.

${ }^{74}$ AFM, untitled orange folder, can be consulted as well as AFS, Registre de procès-verbal des séances du Conseil de la Fondation Scientifique.
} 
transatlantic synergy of philanthropic capitalism added an extra dimension to this joint venture. It enables us to show that, for the Gillet family, the involvement of the Rockefeller Foundation acted as a multiplier, as an auxiliary to an involvement in research and higher education that had begun well before the arrival of the Rockefeller emissaries.

\section{V}

In 1951 Lewis Hackett, a former officer of the International Health Division, interviewed several nursing officers from the Rockefeller Foundation about programmes during the 1920s. One of them described Crowell's final negative judgement about nursing in France as 'a failure' ${ }^{75}$ This amounted to extending to the whole country the swingeing assessment she made in 1939 in a letter to Jean Lépine, concluding: 'After twenty years of contact with Lyon the only satisfaction remaining to me has been the success of the hygiene centre [the school clinic]. ${ }^{76}$ Conversely, Professor Albert Policard of Lyon once said to Alan Gregg that nurse training was the best thing the Rockeller Foundation had ever done in France. ${ }^{77}$ Providing doctors with intelligent and thoughtful ancillaries was certainly not Elizabeth Crowell's main aim.

Yet these contrasting opinions do not suffice to explain the impact of Rockefeller aid in the medical and nursing sector at Lyon. To evaluate this it seems necessary to pursue three exploratory paths. The first concerns the general organization of medical teaching and research. It would be rash to suppose that the new Faculty of Medicine was, in its conception and location, an exact prefiguration of the era of full-time university faculty and hospital service, thirty years ahead of the 1958 regulation, as some people have suggested. ${ }^{78}$ On the other hand, it is undeniable that the complex constituted by the Hôpital Grange Blanche, the Faculty of Medicine and the school for nurses was, along with Strasbourg, one of the first examples in France of an amalgamation of hospitals, medical education, nursing education and research laboratories. Did this imply full-time service in hospitals and the university? Nothing could be less certain and more specific research is required to settle the issue. ${ }^{79}$ Even so, the intervention of the Rockefeller Foundation was decisive in enabling some doctors in Lyon to fulfil their intentions in that direction, and it did substantially shape that fulfilment.

75 RF 3.1/200/7D/86.52, p. 1234.

76 RF 1.1/700/24/272, Crowell to Lépine, 26 July 1939.

77 Cited in Picard, La Fondation Rockefeller, p. 79.

78 For example, the tribute given by Jean François Cier at the Académie de Lyon in 1977, or again the biographical note written by Lepine's former intern, A. Gonin, in the Semaine des Hôpitaux, 26 Jan. 1968. The 1958 ruling created the Centres Hospitaliers Universitaires, uniting teaching, research and hospital care.

79 Picard, La Fondation Rockefeller, final chapter. 
The second avenue of enquiry concerns the style and substance of what was exchanged in the to-and-fro of communications and interconnections on the subject of nursing and medical education. While it might seem at first sight that a bilateral type of relation was at issue here, in which French and American versions of nursing and medical education met head-on, a more searching analysis of the situation has revealed that on both sides the partners shared principles that originated from a composite matrix. The ideal type of the feminine nurse, secular and professionalized, was formed in nurses' conversations that had been going on since the middle of the nineteenth century between protagonists who did not disguise their universalist ambitions. American nurses and their Lyonnais counterparts shared the same level of expectations, defined by the (often rival) efforts of the great Catholic hospital orders, the European Protestant reformers (the pastor Fliedner and his wife, in Kaiserwerth, Florence Nightingale in London and the comtesse de Gasparin at Lausanne) and the leaders of American and British nurses. As a result, no single national label can be applied to the formula implemented by the Rockefeller Foundation at Lyon and elsewhere-short of describing it, lazily, as English and Nightingalian. In a roughly similar vein, the bringing together of medicine, hospitals and laboratories, as urged by the Foundation, was the result of a German synthesis produced in the second half of the nineteenth century, the essential tenets of which were shared by a number of teachers in Lyon. This draws attention to the existence of a European conversation about university medicine, which was in place from the beginning of the nineteenth century. ${ }^{80}$ Yet, once again, it would be facile to describe the Flexner model as American or German and to diagnose the conquest of Europe by an American model. By setting it up as the future for modern academic medicine, the Rockefeller Foundation was in fact able to recycle in France, Belgium and Great Britain and under American colours a formula which, in its Germanic garb, would doubtless have been discredited in the immediate post-war period. ${ }^{81}$ The difficulty of pinning down to a single nation the exchanges in our joint philanthropic venture provides the clue to a third pathway.

This avenue leads to a consideration of the extension of the Lyonnais health scene onto the transnational circuits of practical and scientific knowledge. Not that the scene at Lyon had hitherto been autonomous: Raphael Lépine was not the only Lyon doctor to have made the pilgrimage to the English and German faculties, before and after the war of 1870, and Professor Jules Courmont scoured the tuberculosis congresses and visited Scandinavian hospitals at the

${ }^{80}$ Georges Weisz has shown the underlying role of reciprocal exchanges between the medical centres of Vienna, London and Paris in the development of medical specialization: 'Naissance de la specialisation médicale dans le monde germanophone', Actes de la Recherche en Sciences Sociales, 156-7 (2005), 37-51.

81 One might wonder if the channelling of funds and attention of the Rockefeller Foundation from Strasbourg to Lyon, was not partly the result of a tactical realization of the difficulty involved in convincing European countries to adopt forms of teaching all too easily connected to former enemies. 
beginning of the twentieth century. ${ }^{82}$ However, while the First World War severed the bond of inspiration and emulation that linked French medicine to Germany, the possibilities opened up by Rockefeller aid connected the people of Lyon to the intra-European and transatlantic circuit. This was true of the professors, whether they were content to read the journals and periodicals which the Foundation sent to the European faculties or whether, like Lépine, Mourriquand, Policard, Leriche and Latarjet, they toured United Kingdom and the United States extensively at the Foundation's expense in order to meet their colleagues and visit hospitals and laboratories. This was also true of the following generation, including those young assistants whom Professor Policard sent to Copenhagen, Vienna or Amsterdam for a few months to observe the work of teaching and laboratory research, diverting to this end (with Gregg's agreement) the unused balance of a Rockefeller research subsidy. ${ }^{83}$ Among nurses, and equally among those who worked as bedside or public health nurses, the joint venture of the 1920s also diversified the sources of comparison, inspiration and differentiaton. If, until 1914, English nursing was by proxy the first and last word for the Lyonnais reformers of the 'infirmat', the nursing fellows at Lyon and the young nurses graduating from the Ecole d'Infirmières et de Visiteuses de Lyon et du Sud-Est who benefited from a travel scholarship were able to discover it at first hand. ${ }^{84}$ It was likewise by first-hand experience that they came to know the hospitals, schools and clinics in Poland, Belgium, Hungary, Canada and the United States. They also participated in international congresses organized by the International Council of Nurses. At the same time, they saw the whole parade of established and would-be nurse leaders from many countries passing through Lyon, brought there at the expense of the Rockefeller Foundation for training courses lasting several weeks or for visits of a single day. The symmetry was not perfect in these interactive situations, deliberately created by Elisabeth Crowell in order to generate the interchange of knowledge and methods, with a view to a general modification of the education, knowledge and professional behaviour of French nurses. However, the many visitors from the United States did not come merely to distribute good and bad marks to the Lyonnais pupils and their masters. The nurses of the East Harlem Settlement, the Rockefeller Foundation's demonstration project and the gold standard of public health nursing in the United States at the beginning of the 1920s, were not in Lyon simply to gain a better knowledge of the working conditions of European colleagues and pupils whom they regularly received in New York. Crowell also hoped to teach them, like other overseas visitors, something of the

82 For an account of such visits by professors and interns: H. Mollière, Souvenirs de voyage. L’hôpital général de Vienne, les bôpitaux de Berlin (Lyon, 1882).

83 RF 12.1, Gregg diary, 21 Sept. 1928 and 20 Nov. 1928.

84 On this point: M. Poisson, Histoire de la profession infirmière en France. Origines républicaines d'un modèle infirmier 1870-1900 (Vincennes, 1998). 'Infirmat' was the term that Dr Bourneville, who piloted reform of the system of training at the Assistance Publique hospitals in Paris, tried to introduce to name the vocational field of nursing. 
European experience. When they visited the clinic of the Ecole d'Infirmières et de Visiteuses in July 1933, they praised its thoroughgoing integration into the school's teaching system, something unknown in the New York structures. Moreover, once back in North America, nursing officers from the Foundation often utilized their European experience in practical work and professional discussions. When, in 1938, the New York Department of Health was attempting to devise a family health filing system, in the context of setting up a generalized programme of public health in New York, it was the Lyon clinic that they approached with a request for samples of their files. ${ }^{85}$ While all this did not, admittedly, invert the flow of nursing knowledge, the fact remains that they now passed through Lyon, connecting both hospital nurses and health visitors with their European, North American and Brazilian sisters. ${ }^{86}$ Here, then, the Rockefeller Foundation did not so much contribute to 'Americanizing' the nurses and teachers of medicine at Lyon as to inserting them into a wider circulatory configuration, with its asymmetries, its unevenness and its rivalries. This was a configuration in which national characteristics were ultimately one way among others for participants to situate themselves within a set of principles of vision, division and action that need to be investigated beyond territorial points of reference. At stake is our understanding of projects and undertakings that built up universal claims through a fine-grained assemblage of contextualized elements. The great US philanthropic foundations were important players in the twentieth-century aspects of this history.

85 RF 1.1/700/24/272, Tennant to Crowell, 10 Oct. 1938.

86 For a first approach to these worlds of nursing: P.-Y. Saunier, 'Les régimes circulatoires du domaine social 1800-1940: projets et ingénierie de la convergence et de la différence', Genèses, 71 (2008), 4-25; idem, 'Worlds of nursing: the Rockefeller moment', Rockefeller Archive Center Research Reports (2008), http://archive.rockefeller.edu/publications/resrep/pdf/saunier.pdf. 